\title{
THE IMPACT OF MACROECONOMIC INDICATORS ON VAT REVENUES IN EU COUNTRIES
}

\author{
aLENA ANDREJOVSKÁ, ' MARTINA HELCMANOVSKÁ \\ ${ }^{a b}$ Faculty of Economics, Department of Finance, Technical \\ University of Košice, Boženy Němcovej 32,040 01 Košice, \\ Slovak Republic \\ email: ${ }^{a}$ alena.andrejovska@tuke.sk, ${ }^{b}$ martina.helcmanovska@tuke.sk
}

This research was supported by VEGA project No. 1/0430/19 Investment decisionmaking of investors in the context of effective corporate taxation.

Abstract: The paper deals with the issue of the impact of changes in selected Absract: The paper deas with the issue of The aim of The aim of the paper was to empirically verify this impact. The analysis was perforned using a lin was

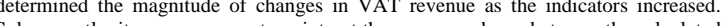
Subsequently, it was necessary to point out the correspondence between the calculated and the actual VAT revenue. The analysis followed GDP, consumption expenditure, exports, imports and the VAT rate in the $28 \mathrm{EU}$ countries for the period 2004-2018, while the countries were considered as a separate territorial unit. The contribution set out a hypothesis that was not confirmed, as GDP had the most significant impact on VAT revenues. This caused the most significant increase in VAT revenue by EUR 139,300 while increasing GDP by 1 million EUR. The calculated VAT revenue based on the compiled econometric model indicated that with slight deviations, it copies the actual value of VAT revenue. Based on the analysis, we can conclude that the selected indicators and the level of the standard rate are variables that affect the amount of VAT revenue.

Keywords: econometric model, macroeconomic determinants, regression analysis, standard VAT rate, VAT revenue.

\section{Introduction}

Revenue to the state budget, the main part of which is tax revenue, is the main mechanism for ensuring economic development. Value added tax, the revenue of which accounts for almost half of all tax revenue within the EU, is financed and secured by the EU's internal market. For the state, value added tax represents an inflow of funds directly into state budgets and is one of the most important taxes that affects every consumer, which is confirmed by many authors (Cnossen 1990; Ebrill et al. 2001; Bendikienè and Šaparnis 2006; Keen and Lockwood 2006). VAT is applied throughout the European Union and is a key instrument of fiscal policy. The importance of this tax covers two levels: the common European market and national markets (Simonides and Feranecová 2017 and Mura et al. 2015).

This contribution is deducted from income only from the standard VAT rate. The rate is determined by each country individually, so rates may vary from country to country, with the rate not being less than $15 \%$ and not more than $27 \%$ (Baskaran and Lopez da Fonsseca 2014). Revenues from this tax vary from different amounts of fixed VAT rates. Based on the development of VAT revenues, revenues since the economic crisis of 2008 have increased in all EU countries. The final amount they receive from VAT is also affected by various factors, such as the level of consumption, from which GDP is derived, which concisely defines the economic situation in a given country.

\section{Literature review}

When fulfilling the state budget, revenue from value added tax is the most important source. The system of collection and payment of value added tax provides opportunities for tax evasion, which, in combination with the high volume of domestic and international transactions, ranks VAT among the most risky taxes. Many authors such as Keen and Smith (2007), Brederode (2008), Tumpach et al. (2014) and Dharmapala (2014) deal with tax evasion. The potential revenue from this tax is the difference between the theoretical VAT base and the VAT actually paid multiplied by the weighted average VAT rate. The theoretical portfolio for the sum of all macroeconomic aggregates for which the need to pay VAT applies is specified by the state (MFSR 2019). Slemrod (2003) evaluates two theoretical directions, namely the traditional school of economics and the modern one, where he summarized the impact of VAT revenue on the economy. The modern school of economics says that in the long run, a higher tax rate contributes to economic prosperity. Subsequently, the government from a higher tax collection can use these funds for the development of the country, which ultimately supports the growth of economies. Bogetic and Hassan (1993) were one of the first authors to address the issue of determinants affecting VAT revenue. Within the EU and Asia, they concluded that one of the variables that affects and increases VAT revenue is the VAT rate.

The effective collection of taxes and the VAT revenue itself is affected by various variables. One such factor is the economic situation in a given country, which best describes GDP as well as GDP per capita. Godin and Hindriks (2015) found in the period from 1980 to 2010 that economic growth, openness of economies and the size of tax rates have a positive effect on VAT revenue. The positive impact of economic openness is also confirmed by Keen and Lockwood (2010), who supplement GDP with it and at the same time say that countries with higher GDP tend to have lower VAT revenues. Hodzic and Celebi (2017) state that for the period from 2009 to 2013 from EU countries, Croatia achieves high VAT revenues expressed as a percentage of GDP. The level of consumption in a particular country is also a crucial variable on which VAT collection depends. Higher consumption of goods and services is associated with higher levels of GDP per capita, which leads to an increase in VAT revenues (Sarmento 2016). Onaolapo et al. (2013) in their contribution to the Nigeria study showed that the VAT rate is statistically significant to VAT revenue, which also speaks to the benefit of this tax for the economy as a whole. Mach (2018) argues that reducing this tax in the Czech Republic can help both the state budget and taxpayers.

The amount of VAT income also depends on the rate of value of imports and exports in a given country. Exports for a country do not constitute VAT revenue as they are subject to a zero tax rate, so increasing it may have a negative impact on VAT revenue. However, an increase in exports may lead to an increase in domestic production, which will be reflected in an increase in household disposable income and a consequent increase in domestic demand. Looking at the relationship between VAT revenue and imports, imports represent a direct income for the country where final consumption takes place, as they are subject to VAT. Thus, an increase in exports represents an increase in tax revenues (Hybka 2009). This fact of a positive effect on VAT revenue is also confirmed by Hines and Desai (2005). According to Bikas and Rashkauskas (2011), unemployment can also be perceived as a macroeconomic determinant that has an impact on VAT revenue. They justified this by stating that VAT revenue is influenced by household consumption, which they refer to as the main VAT payer, depending on the level of wages.

Based on the mentioned literature and Legeida and Sologoub (2003), it can be stated that the economic situation in the country is influenced by macroeconomic determinants, namely GDP, GDP per capita, general consumption expenditure, as well as household and government consumption expenditure, exports, imports and unemployment, which form and affect the amount of VAT income, which also depends on the level of the VAT rate.

\section{Material and methods}

The aim of the paper was to empirically verify the impact of selected macroeconomic determinants and the level of the standard VAT rate on VAT revenues in $28 \mathrm{EU}$ countries. The first part of the paper analyzed the development of the VAT rate and VAT revenues in EU countries. The second part was devoted to regression analysis, where an econometric model was compiled, which tested the impact and then was compared with the actual values of VAT revenue. 
The selection of macroeconomic determinants was made on the basis of the authors' theoretical knowledge: Bogetic and Hassan (1993), Ebrill et al. (2001), Legeida and Sologoub (2003), Hybka (2009), Keen and Lockwood (2010), Bikas and Rashkauskas (2011), Onaolapo et al. (2013), Godin and Hindriks (2015), Glova et al. (2018), Sarmento (2016), who in their research dealt with various determinants and factors that affect VAT revenues.

The source databases were the databases of the Statistical Office of the European Commission EUROSTAT and the Directorate General of the European Commission AMECO. All figures used in the contribution were expressed in EUR million and were annual figures from 2004 to 2018 across the $28 \mathrm{EU}$ countries. The paper uses data on VAT revenues, standard VAT rates and selected macroeconomic determinants (gross domestic product, gross domestic product per capita, consumption expenditure, household and government consumption expenditure, exports, imports and unemployment). Calculations and analysis concerning the correlation coefficient and the econometric model were performed in the $\mathrm{R}$ programming language, in version $\mathrm{R}$ 3.5.0.

To determine and evaluate whether the change in the standard VAT rate also affects the amount of VAT revenue, an analysis of the development of the VAT rate and VAT revenues in EU countries for the period from 2004 to 2018 was performed. From VAT, an analysis of the development of the VAT rate and VAT revenues in EU countries for the period from 2004 to 2018 was performed.

Using Pearson's correlation coefficient, the influence of macroeconomic determinants and the VAT rate on VAT revenue was determined. The coefficient determined the tightness of the dependence between them.

The econometric model was constructed using linear regression analysis. The 28 EU countries were considered as a separate territorial unit, so the values contained in the model were expressed as an arithmetic average. The analysis showed how the amount of VAT revenue changes, whether it increases or decreases, with an increase of one unit, i.e. 1 mil. EUR of selected macroeconomic determinants and by $1 \%$ of the VAT rate. It was also found that the constructed model determining the VAT revenue corresponds to its real value.

The constructed econometric model based on a lineály formulated model had the form:

$$
\begin{gathered}
\operatorname{RfVAT}_{\mathrm{t}}=\beta_{0}+\beta_{1} * \mathrm{GDP}_{\mathrm{t}}+\beta_{2} * \mathrm{CE}_{\mathrm{t}}+\beta_{3} * \mathrm{E}_{\mathrm{t}}+\beta_{4} * \mathrm{I}_{\mathrm{t}}+\beta_{5} * \mathrm{VAT}_{\mathrm{t}} \\
+\mathrm{u}_{\mathrm{t}},
\end{gathered}
$$

where the explained (dependent) variable is:

RfVAT - revenue from the standard rate of value added tax, and the explanatory (independent) variables are:

GDP - gross domestic product,

CE - general consumption expenditure,

E - export,

I - import,

VAT - standard rate of value added tax.

The compiled econometric model according to regression analysis met the assumptions of residue normality, the presence of homoskedasticity and the absence of autocorrelation. The whole compiled model turned out to be statistically significant. Therefore, the model was considered appropriate and can be said to have performed correctly. After estimating the vector of parameters $\beta=(\beta 0, \ldots ., \beta 5)$ a model was created:

$$
\begin{gathered}
\mathrm{y}_{\mathrm{t}}=-19940+0,1393 \mathrm{x}_{1}-0,1243 \mathrm{x}_{2}-0,04709 \mathrm{x}_{3}+0,07989 \mathrm{x}_{4}+ \\
1273 \mathrm{x}_{5}+\mathrm{u}_{\mathrm{t}}
\end{gathered}
$$

Based on the chosen methods, a hypothesis was established in which it is assumed that:
H1: Of the selected variables, the standard VAT rate is the one that is most significant based on the regression analysis in relation to VAT revenue.

\section{Results and discussion}

4.1 Analysis of the development of the VAT rate and revenue from VAT

In EU countries, the standard VAT rate applies, which must not be lower than $15 \%$ and higher than $27 \%$. A table (Table. 1) showing the development and changes in the standard VAT rate in the EU member states for the period from 2004 to 2018 is a part of the annexes (Annex 1). The minimum allowed VAT rate of $15 \%$ for the period was applied by three countries: Luxembourg until 2015, the other is Cyprus, where the minimum VAT rate applied until 2012. The last of these three countries is the United Kingdom, which applied a minimum VAT rate of $15 \%$ in 2008-2009. A higher standard VAT rate of $25 \%$ is applied by Sweden and Denmark, which, together with Austria, Belgium, Bulgaria and Malta, are among the countries where the VAT rate has not changed during the period under review. Hungary also had a standard VAT rate of $25 \%$ until 2012. This year, it started applying the $27 \%$ rate, making it the country with the highest standard VAT rate in the EU.

A table (Table. 2) recording the development and changes in VAT revenues in the EU member states for the period from 2004 to 2018 is a part of the annexes (Annex 2). The countries with the lowest revenue from VAT to state budgets from EU countries are Malta, Latvia, Estonia and Cyprus. By contrast, countries such as Germany, the United Kingdom and France have the highest VAT revenues.

The results of the analysis, which consisted of the arithmetic average of all EU countries for the period under review, showed that the standard VAT rate as well as VAT revenue were most affected by the economic crisis in 2008. The development of the standard VAT rate in 2004-2008 developed almost stably. In the following years 2008 to 2015, the standard VAT rate increased by 2.1 percentage points (from $19.5 \%$ to $21.6 \%$ ), which was affected by fluctuations in the economies caused by the financial crisis. From 2015 to 2018, a minimal decrease of 0.1 percentage point was recorded, where this period can be described as stable after the previous period of significant changes. As for VAT revenues, it grew appropriately in the years 2004 to 2007. Due to the crisis in 2008, VAT revenues decreased compared to 2007 by 451.1 mil. EUR. A more rapid decrease in VAT revenue by 2,918 mil. EUR occurred in 2009. A year later, VAT revenue increased by 2,826.4 mil. EUR and in 2011 we can already talk about growth that exceeded the values before the crisis of 2007 by 1,071 mil. EUR. Since 2010, we can see a regular increase in average VAT revenue in EU countries.

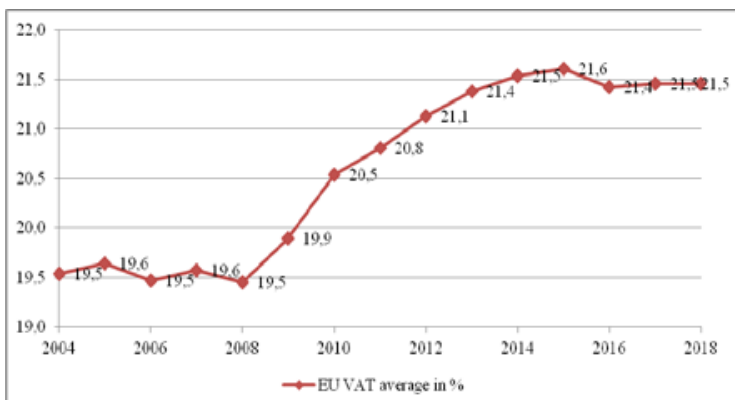

Figure. 1 Development of the average VAT rate in EU countries for the period $2004-2018$

Source: own processing according to EUROSTAT 


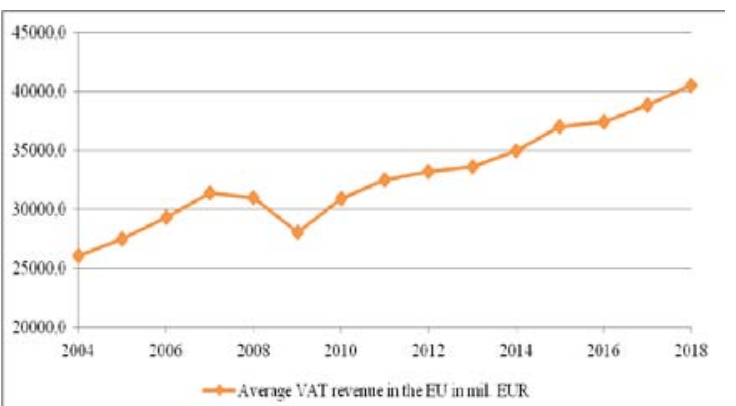

Figure. 2 Development of average VAT revenues in EU countries for the period $2004-2018$

Source: own processing according to EUROSTAT

The crisis in 2008 had the greatest impact on VAT revenue developments in the United Kingdom, Latvia, Italy, Ireland, Spain, Estonia and Denmark, which saw a decline in VAT revenue the following year. The rest of the EU countries were affected by the decline in VAT revenue only in 2009, while in the following year they showed an increase, with the exception of Slovakia and Ireland. An exception is also Luxembourg, which did not experience a decrease in VAT revenue during the crisis until 2015. This year, the country increased its unchanged rate from $15 \%$ to $17 \%$ and VAT revenue decreased by 328 million EUR compared to the previous year. Between 2010 and 2018, Belgium, Estonia, Finland, France, Lithuania, Latvia and Malta saw an increase in VAT revenue. The subsequent economic growth and improvement of the economic situation in the given countries contributed to the growth of VAT revenues, which was helped by increased consumption and investment activity of the state. Others from the mentioned countries recorded only a small decrease between 2010 and 2018 .

The impact of the crisis affected Greece the most, where VAT revenue fell by 1,079 million EUR from 2008 to 2009. To overcome high debts, they increased the standard VAT rate by 4 percentage points the following year and felt an increase in VAT revenue. However, in the next two years they meant a decline. Despite a visible increase from 2014 to 2018, VAT revenues did not reach pre-crisis levels. Ireland also recorded a decrease in 2008 compared to the previous year by 1,271 mil. EUR and it lasted until 2012

In Germany and Austria, the crisis did not affect VAT revenue and it increased every year throughout the period under review. As a result of the crisis, there was an immediate increase in the standard VAT rate in six countries in 2009 and in the following year in another nine countries.

The most significant changes in VAT rates were observed in Hungary, where in 2009 the rate increased from $20 \%$ to $25 \%$. The arrival of the new government and its significant tax reform in 2012 increased the standard rate of value added tax to an incredible $27 \%$. The VAT rate also increased in Romania in 2010 from $19 \%$ to $24 \%$. Due to the reduction of the public finance deficit and the fulfillment of the conditions for obtaining a loan from the IMF. In 2016, the VAT rate was reduced to $20 \%$ and the following year it was reduced to $19 \%$ and is still valid today. In 2010, there were visible changes in Greece as well. VAT rates have risen from $19 \%$ to $23 \%$ in order to obtain financial assistance to repay huge debts. In 2017, the VAT rate was finally adjusted from $23 \%$ to $24 \%$ as part of the promotion of complex reforms in parliament. The VAT rate in Latvia also increased by 3 percentage points from $18 \%$ to $21 \%$ in 2009 . The VAT rate also increased from $16 \%$ to $19 \%$ in Germany in 2007, which should have allowed Germany to get below the upper limit of the state budget of a maximum of $3 \%$ of GDP by 2007 at the latest. Spain is also hit hard by the crisis, with poor public finances and a generally weaker health forcing the government to make changes to the tax system, raising the rate in 2010 VAT from $16 \%$ to $18 \%$.

\subsection{Correlation coefficient}

To estimate whether the selected macroeconomic determinants and the standard VAT rate affect VAT revenues, a correlation coefficient was chosen, which determined the relationship and the size of the dependence between the selected factors. The pvalue has a statistically significant informative value here, by which the colored parts are marked in the table (Table. 3 ).

Table. 1 Correlation coefficient of dependence between VAT revenue and selected determinants in the EU

\begin{tabular}{|c|c|c|c|c|c|c|c|c|c|}
\hline 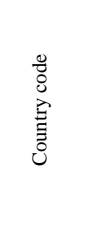 & 莣 & Оิ & 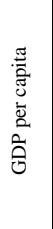 & 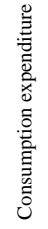 & 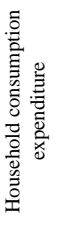 & 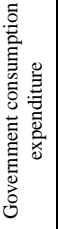 & 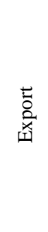 & 家 & 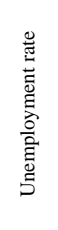 \\
\hline AT & NA & 1,00 & 0,99 & 1,00 & 1,00 & 0,99 & 0,97 & 0,97 & 0,18 \\
\hline $\mathrm{BE}$ & NA & 0,99 & 0,99 & 0,99 & 0,99 & 0,98 & 0,98 & 0,98 & $-0,51$ \\
\hline $\mathrm{BG}$ & NA & 0,97 & 0,97 & 0,98 & 0,97 & 0,97 & 0,96 & 0,98 & $-0,45$ \\
\hline $\mathrm{CY}$ & 0,43 & 0,88 & 0,85 & 0,77 & 0,83 & $\begin{array}{ll}0,42 \\
\end{array}$ & 0,73 & 0,90 & 0,09 \\
\hline $\mathrm{CZ}$ & 0,85 & 0,97 & 0,97 & 0,97 & 0,97 & 0,96 & 0,98 & 0,97 & $-0,80$ \\
\hline$\overline{D E}$ & \begin{tabular}{l|l}
0,78 \\
\end{tabular} & 0,97 & 0,98 & 0,97 & 0,97 & 0,97 & 0,97 & 0,96 & $-0,98$ \\
\hline DK & NA & 0,98 & 0,99 & 0,96 & 0,98 & \begin{tabular}{|c|}
0,88 \\
\end{tabular} & 0,96 & 0,96 & 0,13 \\
\hline$\overline{E E}$ & 0,64 & 0,99 & 0,99 & 0,99 & 0,99 & 0,97 & 0,93 & 0,93 & $-0,44$ \\
\hline EL & $-0,17$ & 0,75 & 0,77 & 0,72 & 0,75 & 0,67 & 0,20 & 0,85 & $-0,58$ \\
\hline ES & 0,71 & 0,51 & 0,55 & 0,45 & 0,56 & $\begin{array}{ll}0,18 \\
\end{array}$ & 0,80 & 0,82 & 0,05 \\
\hline FI & 0,93 & 0,98 & 0,97 & 0,98 & 0,99 & 0,96 & 0,65 & 0,88 & 0,18 \\
\hline FR & 0,83 & 0,98 & 0,95 & 0,95 & 0,96 & 0,93 & 0,98 & 0,98 & 0,41 \\
\hline HR & \begin{tabular}{|l|}
0,71 \\
\end{tabular} & 0,92 & 0,95 & 0,89 & 0,89 & $\begin{array}{l}0,86 \\
\end{array}$ & 0,97 & 0,92 & $-0,22$ \\
\hline $\mathrm{HU}$ & \begin{tabular}{|c|}
0,63 \\
\end{tabular} & 0,94 & 0,95 & 0,86 & 0,86 & 0,84 & 0,91 & 0,90 & $-0,55$ \\
\hline IE & 0,01 & 0,56 & 0,64 & 0,59 & 0,65 & 0,42 & 0,36 & 0,39 & $-0,84$ \\
\hline IT & 0,73 & 0,96 & 0,94 & 0,91 & 0,94 & 0,73 & 0,94 & 0,94 & 0,52 \\
\hline LT & 0,71 & 0,99 & 0,98 & 0,99 & 0,99 & 0,96 & 0,94 & 0,96 & $-0,23$ \\
\hline $\mathrm{LU}$ & 0,59 & 0,94 & 0,94 & 0,96 & 0,95 & 0,96 & 0,92 & 0,92 & 0,77 \\
\hline LV & 0,41 & 0,95 & 0,96 & 0,95 & 0,96 & 0,90 & 0,91 & 0,96 & $-0,49$ \\
\hline MT & NA & 0,99 & 0,99 & 0,99 & 0,99 & 0,97 & 0,97 & 0,94 & $-0,96$ \\
\hline NL & 0,71 & 0,97 & 0,97 & 0,93 & 0,98 & \begin{tabular}{|l|}
0,83 \\
\end{tabular} & 0,91 & 0,90 & $-0,21$ \\
\hline PL & 0,69 & 0,97 & 0,97 & 0,96 & 0,96 & 0,96 & 0,94 & 0,97 & $-0,91$ \\
\hline $\begin{array}{l}\text { PT } \\
\end{array}$ & \begin{tabular}{|l|}
0,71 \\
\end{tabular} & 0,88 & 0,90 & 0,78 & $\begin{array}{l}0,87 \\
\end{array}$ & $-0,05$ & 0,92 & 0,96 & $-0,13$ \\
\hline $\mathrm{RO}$ & 0,45 & 0,89 & 0,89 & 0,87 & 0,88 & 0,80 & 0,86 & 0,90 & $\begin{array}{l}-0,58 \\
\end{array}$ \\
\hline SE & $\mathrm{N}$ & 0,99 & 0,98 & 0,99 & 0,99 & 0,99 & 0,96 & 0,97 & $-0,14$ \\
\hline SI & 0,74 & 0,99 & 0,99 & 0,91 & 0,92 & 0,87 & 0,97 & 0,98 & 0,04 \\
\hline SK & 0,78 & 0,97 & 0,97 & 0,96 & 0,96 & 0,97 & 0,96 & 0,97 & $-0,82$ \\
\hline UK & 0,83 & 0,95 & 0,86 & 0,96 & 0,96 & 0,89 & 0,95 & 0,96 & $-0,46$ \\
\hline $\begin{array}{c}\text { EU } \\
\text { average }\end{array}$ & 0,85 & 0,99 & 0,99 & 0,99 & 0,98 & 0,95 & 0,99 & 0,99 & $-0,06$ \\
\hline
\end{tabular}

Source: own processing according to EUROSTAT

It is clear from the table (Tab. 3) that the unemployment rate indicator shows negative values, which indicates a negative correlation and means that an increase in the unemployment rate affects the decline in VAT revenues (negative relationship). The exceptions are Italy and Luxembourg, where a positive relationship applies. For all other indicators, plus values came out, which shows a positive correlation, and thus when the value of the indicator of the independent variable increases, there is always an increase in the dependent variable, i.e. our VAT revenue.

The EU average, which expresses a separate territorial unit, has the strongest relationship, i.e. very close correlation (correlation coefficient 0.99) achieved for the indicators GDP, GDP per capita, consumption expenditure, exports (exports) and imports (imports). Another strong relationship (correlation coefficient 0.98 and 0.95) exists between the indicators household consumption expenditure and government consumption expenditure. The medium close correlation (correlation coefficient 0.85 ) is represented by the indicator of the standard VAT rate. The relationship between the indicators VAT revenue and the unemployment rate expresses a negative relationship and at the correlation coefficient -0.06 it represents practically no correlation.

The strongest relationship with the value of the correlation coefficient of 0.99 - 0.96 from individual EU countries was found in Austria, Belgium, Bulgaria, the Czech Republic, Germany, Sweden and Slovakia. However, most countries 
achieved a strong relationship (correlation coefficient values above 0.90 ) in the indicators of imports (24 countries), GDP, GDP per capita and exports (22 countries), consumption expenditure, household consumption expenditure (20 countries) and government expenditure. consumption (15 countries).

On the contrary, the weakest and according to the p-value insignificant relationship was achieved in 17 countries with the unemployment rate indicator. Also for the indicator, government consumption expenditure was found in the countries of Cyprus, Spain, Ireland and Portugal. If we evaluate the countries separately, Spain shows insignificant values in terms of GDP, consumption expenditure and government consumption. Ireland, on the other hand, spends on government consumption, imports and exports.

Macroeconomic determinants of GDP, consumption expenditures, exports, imports and the standard VAT rate were selected for the econometric model expressing VAT revenue on the basis of calculated average values of EU countries.

\subsection{Regression analysis}

The results of the econometric model using linear regression analysis are contained in the table (Table. 4). The model expresses the relationship between the VAT revenue rate and the vector of regressors, which are macroeconomic determinants and the standard VAT rate.

Table. 2 Overview of the results of the regression analysis of the VAT revenue model

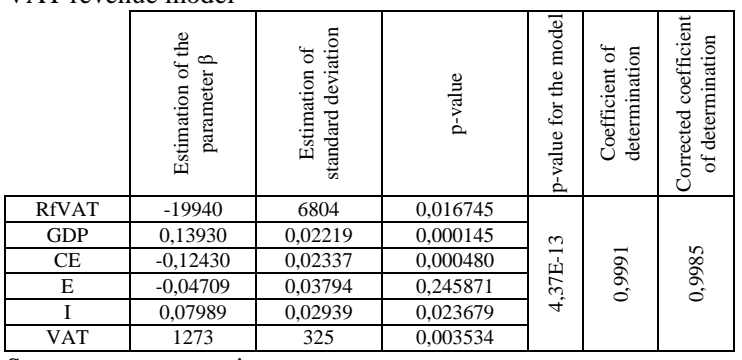

Source: own processing

Based on testing of the model as a whole, it was found that at least one regression coefficient is non-zero, i.e. is statistically significant because the resulting $\mathrm{p}$-value $=4.37 \mathrm{E}-13$ for the model is lower than the determined significance level $\alpha=0.05$. When testing the significance of the estimated regression coefficients, the p-value of all regressors except exports is lower than the specified level of significance, which means that they are statistically significant.

From the output of the analysis it is clear that the coefficient $\beta 0$ $=-19940$ is an estimate of the level constant, which says that the amount of VAT revenue would be $-19,940$ mil. EUR if the variables in the model were equal to zero. This means that if the VAT rate were not applied, the state treasury would not receive revenue from this tax collected from individual determinants in the model, and so the EU as a separate territorial unit would lose this part of the money, i.e. 19,940 mil. EUR. Estimates of the regression coefficients $\beta 1, \beta 2, \beta 3, \beta 4$ and $\beta 5$ are other values in the model, which express that if a variable in the model changes by one mil. EUR, the value depends on the value of the estimated regression coefficient. GDP is the first independent variable in the compiled model and represents the statistically most significant determinant according to the p-value of 0.000145 . The regression coefficient is 0.13930 , which indicates a positive relationship to VAT revenue, which is also mentioned by Keen and Lockwood (2010). The coefficient says that if GDP increases by 1 mil. EUR, so the VAT revenue will increase by EUR 139,300. The second variable is consumption expenditure, which is also the second most statistically significant according to the p-value of 0.000480 . For the given variable, a regression coefficient of -0.12430 was issued, which speaks of a negative effect on VAT revenue, and thus if consumption expenditures increase by 1 mil. EUR, so the VAT revenue will decrease by EUR 124,300. The third in the model is the export, which according to the p-value of 0.245871 is statistically insignificant with the value of the regression coefficient of -0.04709 . Assuming statistical significance, it would have a negative relationship to VAT revenue, and thus with an increase in exports of 1 mil. EUR, VAT revenue would decrease by EUR 47 090. This means that all goods exported from the country are subject to taxation in the country to which they are imported, and thus in the exporting country it would represent a decrease in VAT revenue by the value of the coefficient. Another variable in the model is the import, which is statistically significant according to the achieved p-value of 0.023679 . According to the regression coefficient with a value of 0.07989 , it expresses a positive relationship, and thus with an increase in imports by 1 mil. EUR, VAT revenue will also increase by EUR 79,890. Hines and Desai (2005), Hybka (2009) and Fila et al. (2020) came to the same view, which means that all goods are subject to taxation on importation into the country of importation, which is a separate EU territorial unit. The last variable is the standard VAT rate, at which we can notice the statistical significance according to the p-value at the level of 0.003534 , the significance of the VAT rate was also published by Onaolapo et al. (2013). Also the regression coefficient indicating a positive relationship with the value of 1273 . The coefficient says that if the VAT rate is increased by $1 \%$, the VAT revenue will increase by 1,273 mil. EUR. This positive relationship was also confirmed by Bogetic and Hassan (1993).

The quality of the model adjustment according to the coefficient of determination $=0.9991$ means that approximately $99.91 \%$ of the total variability of the dependent variable, i.e. VAT revenue is explained by the chosen model and the remaining variability is caused by the element of chance and other factors.

By testing the normality of the residues by the Shapir-Wilk test, the p-value was 0.9999 higher than the level of significance, therefore the residues are from the normal distribution. When testing the heteroskedasticity of the Breusch-Pagan model, the resulting p-value was 0.3303 , and thus higher than the significance level $\alpha=0.05$, from which it is assumed that the data are not heteroskedastic. The Breusch-Godfrey test was used to test the autocorrelation in the model, where the resulting pvalue of 0.1227 was greater than the level of significance, making the model suitable because the autocorrelation was not confirmed. The presence of multicollinearity in the model was confirmed, but we chose to ignore it.

To compile the VAT revenue model and to determine the relationship, all five selected variables were also used with exports, so as not to reduce the significance of the model as a whole, which explains $99.91 \%$ of the VAT revenue variability. How the compiled model corresponds to the actual development of VAT revenue and calculated, shows the following graph (Figure. 3), which with selected variables with $0.32 \%$ deviation characterizes VAT revenue for the period from 2004 to 2018. The calculated model would be based on regression analysis could be used to determine VAT revenue on the basis of selected macroeconomic determinants and the standard VAT rate.

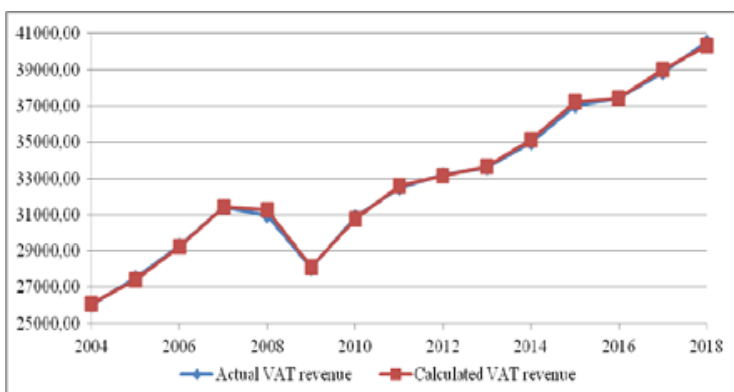

Figure. 3 Actual and calculated values of VAT revenue in mil. EUR for the period 2004-2018

Source: own processing 


\section{Conclusion}

In EU countries, the correct setting of the VAT rate, which is in the hands of individual governments, plays an important role. Revenues from this tax are important revenues to the state treasury. However, the amount of this VAT revenue is not only affected by the level of the VAT rate itself but also by other factors. In the analysis of the development of the standard VAT rate and VAT revenues, countries such as Sweden, Denmark, Austria, Belgium, Bulgaria and Malta are among those in which the standard VAT rate has not changed throughout the period under review. Of these countries, in Belgium and Malta, VAT revenue increased annually, except for 2009. At a constant rate of $20 \%$, revenue grew only in Austria. On this basis, it can be concluded that the VAT rate is not a decisive factor influencing the amount of VAT revenue in the six countries concerned. This analysis already indicated a failure to confirm the established hypothesis. Based on the calculated positive correlation coefficients, an econometric model was compiled, where all macroeconomic determinants except exports proved to be statistically significant using regression analysis. With an increase in individual determinants by 1 mil. EUR proved to be the most influential factor of GDP influencing VAT revenue, which was also the most statistically significant, which did not confirm the established hypothesis about the significance of the VAT rate. The constructed econometric model with selected variables explains $99.91 \%$ of the variability of VAT revenue and, when compared, almost faithfully copies the actual VAT revenue. In conclusion, it can be stated that the standard VAT rate and selected macroeconomic determinants in the constructed model affect the amount of VAT revenue.

\section{Literature:}

1. AMECO.: Macro-economic database AMECO. 2019. [Online] Available: https://ec.europa.eu/info/business-economyeuro/indicators-statistics/economic-databases/macro-economicdatabase-ameco/download-annual-data-set-macro-economic-dat abase-ameco_en (28 december 2019).

2. Baskaran, T., Lopes da Fonseca, M.: The Economics and Empirics of Tax Competition: A Survey and Lessons for the EU. Erasmus Law Review. 2014. [Online] Available: http://dx.doi.or g/10.5553/elr.000015 (28 december 2019).

3. Bendikienè, D., Šaparnis, G.: Changes in the Imposition of Value Added Tax in Lithuania (1994-2004). Engineering Economics. 2006, 47(2): 23-29.

4. Bikas, E., Rashkauskas, J.: Value added tax dimension: the case od Lithuania. Ekonomika. 2010, 90(1): 22-38.

5. Bogetic, Z., Hassan, F.: Determinats of value-added tax revenue. Policy research. Working paper, WPS 1203. October 1993.

6. Brederode, R.: Third-party risks and liabilities in case of VAT fraud in the EU. International tax journal. 2008, 19: 31-32.

7. Cnossen, S.: Taxing value added: the OECD experience. International VAT monitor. Amsterdam. May 1990, (5): 2-16. 8. Dharmpala, D.: What do we know abour base erosion and profit shifting? A review of the empirical literature. Coasesandor institute for law \& economics. Working paper (702). September 2014.

9. Ebrill, L., Keen, M., Bodin, J-P., Summers, V.: The modern VAT. International monetary fund. Washington, DC. 2001.

10. EUROSTAT.: Main national accounts tax aggregates. 2019. [Online] Available: https://appsso.eurostat.ec.europa.eu/nui/sho w.do?dataset=gov_10a_taxag\&lang=en (29 december 2019).

11. Fila, M., Levicky, M., Mura, L., Maros, M., Korenkova, M.: Innovations for Business Management: Motivation and Barriers. Marketing and Management of Innovations. 2020, 4, 266-278. http://doi.org/10.21272/mmi.2020.4-22.

12. Glova, J., Mrazkova, S., Dancakova, D.: Measurement of Intangibles and Knowledge: An Empirical Evidence. Ad Alta: Journal of Interdisciplinary Research. 2018, 8(1): 76-80.

13. Glova, J., Dancakova, D., Suleimenova, Sh.: Managerial Aspect of Intangibles: Own Development or External Purchased Intangible Assets - What Does Really Count? Polish Journal of Management Studies. 2018, 1(2): 84-93.
14. Glova, J., Mrazkova, S.: Impact of Intangibles on Firm Value: An Empirical Evidence from European Public Companies. EKONOMICKY CASOPIS. 2018, 66(7): 665-680.

15. Godin, M., Hindriks, J.: A Review of critical issues on tax design and tax administration in a global economy and developing countries. Center for operations research and econometrics, Core discussion paper (28). June 2015.

16. Hines, J., Desai, M.: Value-added taxes and international trades: The evidence. The law and economics workshop. November 2005.

17. Hodzic, S., Celebi, H.: Value-added tax and its efficiency: EÚ-28 and Turkey. UTMS Journal of economics. 2017, 8(2): 79-90.

18. Hybka, M.M.: VAT collection efficiency in Poland before and after accession to the European Union a comparative analysis. Ekonomika. 2009, 7-18 p. ISSN 1392-1258.

19. Keen, M., Lockwood, B.: Is the VAT a Money machine. National Tax Journal. 2006, (4): 910-924.

20. Keen, M., Lockwood, B.: The value added tax: Its causes and consequences. Journal of development economics. 2010, 92(2): 138-151.

21. Keen, M., Smith, S.: VAT fraud and evasion: What do we know, and what can be done? International monetary fund. Working paper. February 2007.

22. Legeida, N., Sologoub, D.: Modeling Value Added Tax (VAT) Revenues in a Transition Economy: Case of Ukraine. Institute for economic research and policy consulting. Working paper. 2003, (22): 1-21.

23. Mach, P.: VAT rates and their impact on business and tax revenue. European research studies journal. 2018, 21(1): 144-152. 24. MFSR.: Dane a daňová medzera. 2019. [Online] Available: https://www.mfsr.sk/sk/financie/institut-financnej-politiky/pub likacie-ifp/manualy/23-danova-medzera-dph.html/ (10 april 2020). 25. Mura, L., Sleziak, J.: Innovation and Entrepreneurship Network. CERS 2014: 5th Central European Conference in Regional Science. International Conference Proceedings. 2015, 643-651 p. ISBN 978-80-553-2015-1.

26. Onaolapo, A. A-R., Aworemi, R. J., Ajala, O. A.: Assessment od value added tax and its effects on revenue generation in Nigeria. International journal of business and social science. 2013, 4(1): 220-225.

27. Sarmento, J.: The determinants of value added tax revenues in the european union. The european journal of managements studies. 2016, 21(2): 79-99.

28. Simonidesová, J., Feranecová, A.: Dane podnikatel'ských subjektov. Vydavatel'stvo EKONÓM. Bratislava. 2017, ISBN 978-80-225-4402-3.

29. Slemrod, J.: The truth about taxes and economic growth. Challenge. 2003, 46(1): 5-14.

30. Tumpach, M., Uzik, J., Juhaszova, Z.: Irregularities in accounting for provision in Slovakia. Conference: 7th International Scientific Conference on Managing and Modelling of Financial Risks Location. 2014, 824-831 p.

\section{Primary Paper Section: A}

Secondary Paper Section: AH 


\section{Annexes}

\section{Annex 1}

Table. 3 Development of VAT in EU countries for the period $2004-2018$

\begin{tabular}{|c|c|c|c|c|c|c|c|c|}
\hline \multirow{2}{*}{ Country } & \multicolumn{8}{|c|}{ Standard rate of value added tax in \% } \\
\hline & ఫે & $\stackrel{\text { Lิ }}{\stackrel{N}{े}}$ & 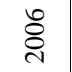 & & $\stackrel{\infty}{\stackrel{N}{े}}$ & \&े & 을 & $\overrightarrow{\bar{\nu}}$ \\
\hline Austria & 20 & 20 & 20 & 20 & 20 & 20 & 20 & 20 \\
\hline Belgium & 21 & 21 & 21 & 21 & 21 & 21 & 21 & 21 \\
\hline Bulgaria & 20 & 20 & 20 & 20 & 20 & 20 & 20 & 20 \\
\hline Cyprus & 15 & 15 & 15 & 15 & 15 & 15 & 15 & 15 \\
\hline $\begin{array}{c}\text { Czech } \\
\text { Republic }\end{array}$ & 19 & 19 & 19 & 19 & 19 & 19 & 20 & 20 \\
\hline Germany & 16 & 16 & 16 & 19 & 19 & 19 & 19 & 19 \\
\hline Denmark & 25 & 25 & 25 & 25 & 25 & 25 & 25 & 25 \\
\hline Estonia & 18 & 18 & 18 & 18 & 18 & 20 & 20 & 20 \\
\hline Greece & 18 & 19 & 19 & 19 & 19 & 19 & 23 & 23 \\
\hline Spain & 16 & 16 & 16 & 16 & 16 & 16 & 18 & 18 \\
\hline Finland & 22 & 22 & 22 & 22 & 22 & 22 & 23 & 23 \\
\hline France & 19,6 & 19,6 & 19,6 & 19,6 & 19,6 & 19,6 & 19,6 & 19,6 \\
\hline Croatia & 22 & 22 & 22 & 22 & 22 & 23 & 23 & 23 \\
\hline Hungary & 25 & 25 & 20 & 20 & 20 & 25 & 25 & 25 \\
\hline Ireland & 21 & 21 & 21 & 21 & 21 & 21,5 & 21 & 21 \\
\hline Italy & 20 & 20 & 20 & 20 & 20 & 20 & 20 & 20 \\
\hline Lithuania & 18 & 18 & 18 & 18 & 18 & 19 & 21 & 21 \\
\hline Luxembourg & 15 & 15 & 15 & 15 & 15 & 15 & 15 & 15 \\
\hline Latvia & 18 & 18 & 18 & 18 & 18 & 21 & 21 & 22 \\
\hline Malta & 18 & 18 & 18 & 18 & 18 & 18 & 18 & 18 \\
\hline Netherlands & 19 & 19 & 19 & 19 & 19 & 19 & 19 & 19 \\
\hline Poland & 22 & 22 & 22 & 22 & 22 & 22 & 22 & 23 \\
\hline Portugal & 19 & 21 & 21 & 21 & 20 & 20 & 21 & 23 \\
\hline Romania & 19 & 19 & 19 & 19 & 19 & 19 & 24 & 24 \\
\hline Sweden & 25 & 25 & 25 & 25 & 25 & 25 & 25 & 25 \\
\hline Slovenia & 20 & 20 & 20 & 20 & 20 & 20 & 20 & 20 \\
\hline Slovakia & 19 & 19 & 19 & 19 & 19 & 19 & 19 & 20 \\
\hline $\begin{array}{l}\text { United } \\
\text { Kingdom }\end{array}$ & 17,5 & 17,5 & 17,5 & 17,5 & 15 & 15 & 17,5 & 20 \\
\hline EU average & 19,5 & 19,6 & 19,5 & 19,6 & 19,5 & 19,9 & 20,5 & 20,8 \\
\hline
\end{tabular}

\begin{tabular}{|c|c|c|c|c|c|c|c|}
\hline \multirow[b]{2}{*}{ Country } & \multicolumn{7}{|c|}{ Standard rate of value added tax in \% } \\
\hline & $\underset{\sim}{*}$ & $\stackrel{m}{\stackrel{n}{\sim}}$ & 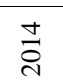 & $\stackrel{n}{\stackrel{2}{\sim}}$ & $\stackrel{0}{\stackrel{2}{N}}$ & $\overrightarrow{\tilde{N}}$ & $\stackrel{\infty}{\stackrel{\sim}{\sim}}$ \\
\hline Austria & 20 & 20 & 20 & 20 & 20 & 20 & 20 \\
\hline Belgium & 21 & 21 & 21 & 21 & 21 & 21 & 21 \\
\hline Bulgaria & 20 & 20 & 20 & 20 & 20 & 20 & 20 \\
\hline Cyprus & 17 & 18 & 19 & 19 & 19 & 19 & 19 \\
\hline $\begin{array}{c}\text { Czech } \\
\text { Republic }\end{array}$ & 20 & 21 & 21 & 21 & 21 & 21 & 21 \\
\hline Germany & 19 & 19 & 19 & 19 & 19 & 19 & 19 \\
\hline Denmark & 25 & 25 & 25 & 25 & 25 & 25 & 25 \\
\hline Estonia & 20 & 20 & 20 & 20 & 20 & 20 & 20 \\
\hline Greece & 23 & 23 & 23 & 23 & 23 & 24 & 24 \\
\hline Spain & 18 & 21 & 21 & 21 & 20 & 21 & 21 \\
\hline Finland & 23 & 24 & 24 & 24 & 24 & 24 & 24 \\
\hline France & 19,6 & 19,6 & 20 & 20 & 20 & 20 & 20 \\
\hline Croatia & 25 & 25 & 25 & 25 & 25 & 25 & 25 \\
\hline Hungary & 27 & 27 & 27 & 27 & 27 & 27 & 27 \\
\hline Ireland & 23 & 23 & 23 & 23 & 23 & 23 & 23 \\
\hline Italy & 21 & 21 & 22 & 22 & 22 & 22 & 22 \\
\hline Lithuania & 21 & 21 & 21 & 21 & 21 & 21 & 21 \\
\hline Luxembourg & 15 & 15 & 15 & 17 & 17 & 17 & 17 \\
\hline Latvia & 22 & 21 & 21 & 21 & 21 & 21 & 21 \\
\hline Malta & 18 & 18 & 18 & 18 & 18 & 18 & 18 \\
\hline Netherlands & 19 & 21 & 21 & 21 & 21 & 21 & 21 \\
\hline Poland & 23 & 23 & 23 & 23 & 23 & 23 & 23 \\
\hline Portugal & 23 & 23 & 23 & 23 & 23 & 23 & 23 \\
\hline Romania & 24 & 24 & 24 & 24 & 20 & 19 & 19 \\
\hline Sweden & 25 & 25 & 25 & 25 & 25 & 25 & 25 \\
\hline Slovenia & 20 & 20 & 22 & 22 & 22 & 22 & 22 \\
\hline Slovakia & 20 & 20 & 20 & 20 & 20 & 20 & 20 \\
\hline $\begin{array}{l}\text { United } \\
\text { Kingdom }\end{array}$ & 20 & 20 & 20 & 20 & 20 & 20 & 20 \\
\hline EU average & 21,1 & 21,4 & 21,5 & 21,6 & 21,4 & 21,5 & 21,5 \\
\hline
\end{tabular}


Annex 2

Table. 4 Development and changes in VAT revenues in EU countries for the period 2004-2018

\begin{tabular}{|c|c|c|c|c|c|}
\hline \multirow{2}{*}{ Country } & \multicolumn{5}{|c|}{ Revenues from VAT in mil. EUR } \\
\hline & 2004 & 2005 & 2006 & 2007 & 2008 \\
\hline Austria & 18545,3 & 19368,4 & 19689,1 & 20922,2 & 21884,3 \\
\hline Belgium & 20404,3 & 21533,3 & 22849,8 & 24140,1 & 24746,1 \\
\hline Bulgaria & 2010,6 & 2377,5 & 2834,8 & 3190,2 & 3862,2 \\
\hline Cyprus & 1053,5 & 1241,9 & 1418,9 & 1627,8 & 1816,2 \\
\hline $\begin{array}{l}\text { Czech } \\
\text { Republic }\end{array}$ & 6416,2 & 7223,1 & 7541 & 8365,9 & 10437,2 \\
\hline Germany & 137445 & 139801 & 147137 & 170067 & 175869 \\
\hline Denmark & 18957 & 20753,9 & 22380,2 & 23439,6 & 23319,7 \\
\hline Estonia & 805,8 & 908 & 1214,9 & 1423,2 & 1287,7 \\
\hline Greece & 12578 & 13398 & 14755 & 16511 & 16978 \\
\hline Spain & 51272 & 57716 & 62365 & 62743 & 52347 \\
\hline Finland & 13010 & 13748 & 14537 & 15207 & 15658 \\
\hline France & 120224 & 126624 & 131693 & 136542 & 137737 \\
\hline Croatia & 3977 & 4362,8 & 4828,5 & 5207 & 5674 \\
\hline Hungary & 7278,3 & 7484,6 & 6812,8 & 8009,8 & 8224,1 \\
\hline Ireland & 10986 & 12373 & 13746 & 14355 & 13084 \\
\hline Italy & 81515 & 85324 & 92221 & 95567 & 93698 \\
\hline Lithuania & 1175,4 & 1488,2 & 1825,6 & 2330,4 & 2593 \\
\hline $\begin{array}{c}\text { Luxembou } \\
\text { rg }\end{array}$ & 1656,9 & 1850,4 & 1897,5 & 2279,9 & 2384,9 \\
\hline Latvia & 779,4 & 1011,2 & 1373,6 & 1733,2 & 1538,1 \\
\hline Malta & 333,6 & 396,9 & 409,8 & 420 & 458,4 \\
\hline $\begin{array}{c}\text { Netherland } \\
\text { s }\end{array}$ & 35587 & 36950 & 39888 & 41952 & 43308 \\
\hline Poland & 14633,3 & 18837,4 & 22126,9 & 25860,4 & 29007,1 \\
\hline Portugal & 11568,7 & 13001 & 13763,6 & 14333,4 & 14424 \\
\hline Romania & 4074,7 & 6439,3 & 7740,8 & 10078,7 & 11036,3 \\
\hline Sweden & 25642,1 & 26739,6 & 28507,3 & 30549,4 & 30941 \\
\hline Slovenia & 2316,8 & 2472,9 & 2648,3 & 2923 & 3167,2 \\
\hline Slovakia & 2639,8 & 3028,1 & 3320,3 & 3699 & 4453,5 \\
\hline $\begin{array}{c}\text { United } \\
\text { Kingdom }\end{array}$ & $\begin{array}{c}\text { 121807, } \\
7\end{array}$ & $\begin{array}{c}\text { 123764 } \\
3\end{array}$ & $\begin{array}{c}130570 \\
8\end{array}$ & $\begin{array}{c}\text { 136405, } \\
9\end{array}$ & $\begin{array}{c}\text { 117319, } \\
3\end{array}$ \\
\hline $\begin{array}{c}\text { EU } \\
\text { average }\end{array}$ & 26024,8 & 27507,7 & 29289,2 & 31424,4 & 30973,3 \\
\hline
\end{tabular}

\begin{tabular}{|c|c|c|c|c|c|}
\hline \multirow{2}{*}{ Country } & \multicolumn{5}{|c|}{ Revenues from VAT in mil. EUR } \\
\hline & 2009 & 2010 & 2011 & 2012 & 2013 \\
\hline Austria & 22105,4 & 22682,3 & 23393,5 & 24506,5 & 24894,5 \\
\hline Belgium & 24390,7 & 25628,4 & 26504,4 & 27420,2 & 27738,1 \\
\hline Bulgaria & 3156 & 3299,1 & 3361,6 & 3768,5 & 3898,1 \\
\hline Cyprus & 1545,6 & 1597,4 & 1516,9 & 1577,5 & 1403 \\
\hline $\begin{array}{c}\text { Czech } \\
\text { Republic }\end{array}$ & 9783,5 & 10419,9 & 11245,8 & 11376,8 & 11694,5 \\
\hline Germany & 177701 & 180213 & 189910 & 194034 & 197005 \\
\hline Denmark & 22498,6 & 23039,6 & 23682,4 & 24398,9 & 24320,3 \\
\hline Estonia & 1224 & 1257,2 & 1363 & 1508 & 1557,9 \\
\hline Greece & 14879 & 15958 & 15021 & 13713 & 12593 \\
\hline Spain & 36786 & 55318 & 54101 & 55021 & 60314 \\
\hline Finland & 15176 & 15533 & 17315 & 17987 & 18888 \\
\hline France & 130303 & 135578 & 140552 & 142527 & 144490 \\
\hline Croatia & 5051,8 & 5161,5 & 5072 & 5402,7 & 5508,4 \\
\hline Hungary & 7820,2 & 8442 & 8516,5 & 9084,1 & 9073,2 \\
\hline Ireland & 10324 & 10067 & 9755 & 10219 & 10372 \\
\hline Italy & 86231 & 97042 & 98257 & 95768 & 93571 \\
\hline Lithuania & 1960,8 & 2180,5 & 2443,8 & 2520,8 & 2611,2 \\
\hline $\begin{array}{c}\text { Luxembou } \\
\text { rg }\end{array}$ & 2469,2 & 2608,2 & 2890,7 & 3171 & 3427,7 \\
\hline Latvia & 1109,2 & 1192,2 & 1367,5 & 1582,6 & 1693,4 \\
\hline Malta & 456,8 & 477,1 & 520,1 & 540 & 582,2 \\
\hline $\begin{array}{c}\text { Netherland } \\
\mathrm{s}\end{array}$ & 41267 & 41840 & 41900 & 41777 & 42408 \\
\hline Poland & 23006,3 & 27465,6 & 29764,4 & 27783,4 & 27780,1 \\
\hline Portugal & 11971,2 & 13527,1 & 14264,9 & 13994,9 & 13709,7 \\
\hline Romania & 7852,3 & 9493,9 & 11411,5 & 11003,1 & 11709,6 \\
\hline Sweden & 28199,4 & 33825,4 & 36630,9 & 37834 & 39047,9 \\
\hline Slovenia & 2850,8 & 2926 & 2995,2 & 2887,7 & 3045,5 \\
\hline Slovakia & 4221,3 & 4182,1 & 4710,9 & 4327,7 & 4696,1 \\
\hline $\begin{array}{l}\text { United } \\
\text { Kingdom }\end{array}$ & 91209,3 & $\begin{array}{c}\text { 113733 } \\
3\end{array}$ & $\begin{array}{c}\text { 130733 } \\
5\end{array}$ & $\begin{array}{c}143622 \\
3\end{array}$ & $\begin{array}{c}143242 \\
4\end{array}$ \\
\hline $\begin{array}{c}\text { EU } \\
\text { average }\end{array}$ & 28055,3 & 30881,7 & 32471,4 & 33191,3 & 33617 \\
\hline
\end{tabular}




\begin{tabular}{|c|c|c|c|c|c|}
\hline \multirow{2}{*}{ Country } & \multicolumn{5}{|c|}{ Revenues from VAT in mil. EUR } \\
\hline & 2014 & 2015 & 2016 & 2017 & 2018 \\
\hline Austria & 25385,5 & 26247,3 & 27301,4 & 28304,3 & 29323,4 \\
\hline Belgium & 27804,3 & 27951,5 & 29179,2 & 30254,7 & 31545,1 \\
\hline Bulgaria & 3809,8 & 4059,4 & 4417,1 & 4663,7 & 5096,5 \\
\hline Cyprus & 1512 & 1516,7 & 1663,6 & 1851,4 & 2088,6 \\
\hline $\begin{array}{l}\text { Czech } \\
\text { Republic }\end{array}$ & 11602,4 & 12217,2 & 13091,5 & 14720,7 & 15929,3 \\
\hline Germany & 203081 & 211616 & 218779 & 226582 & 235130 \\
\hline Denmark & 24949,6 & 25671,9 & 26769,7 & 27965,6 & 29121,2 \\
\hline Estonia & 1711,1 & 1873 & 1975,1 & 2148,7 & 2330,7 \\
\hline Greece & 12676 & 12885 & 14333 & 14642 & 15288 \\
\hline Spain & 64091 & 69294 & 71752 & 75599 & 79264 \\
\hline Finland & 18948 & 18974 & 19694 & 20404 & 21364 \\
\hline France & 148454 & 151680 & 154490 & 161932 & 168902 \\
\hline Croatia & 5455,2 & 5698,5 & 5992,4 & 6464,7 & 6945,8 \\
\hline Hungary & 9754 & 10675,9 & 10595,4 & 11729,2 & 12949,7 \\
\hline Ireland & 11527 & 11831 & 12603 & 13060 & 14158 \\
\hline Italy & 96567 & 100345 & 102086 & 107576 & 109362 \\
\hline Lithuania & 2764,4 & 2889 & 3027,6 & 3310,4 & 3522,2 \\
\hline $\begin{array}{c}\text { Luxembou } \\
\text { rg }\end{array}$ & 3746,8 & 3418,8 & 3423,2 & 3435 & 3729,5 \\
\hline Latvia & 1787,3 & 1876,3 & 2032 & 2163,7 & 2449,1 \\
\hline Malta & 642,2 & 673,3 & 711,6 & 810,2 & 919,7 \\
\hline $\begin{array}{l}\text { Netherland } \\
\text { s }\end{array}$ & 42951 & 44746 & 47849 & 49833 & 52619 \\
\hline Poland & 29317 & 30074,8 & 30838,4 & 36329,8 & 40410,7 \\
\hline Portugal & 14681,6 & 15367,9 & 15767,1 & 16809,5 & 17865,4 \\
\hline Romania & 11496,3 & 12939,2 & 10968,4 & 11650,5 & 12889,9 \\
\hline Sweden & 38845,9 & 40501,4 & 42770,2 & 44115,1 & 43433,1 \\
\hline Slovenia & 3154,8 & 3219,7 & 3318,5 & 3481,7 & 3765,3 \\
\hline Slovakia & 5021,1 & 5422,5 & 5423,6 & 5918,7 & 6319,3 \\
\hline $\begin{array}{c}\text { United } \\
\text { Kingdom }\end{array}$ & $\begin{array}{c}\text { 158347 } \\
4\end{array}$ & $\begin{array}{c}\text { 183164, } \\
3\end{array}$ & $\begin{array}{c}\text { 167827 } \\
2\end{array}$ & $\begin{array}{c}\text { 162723 } \\
7\end{array}$ & 168688 \\
\hline $\begin{array}{c}\text { EU } \\
\text { average }\end{array}$ & 35003 & 37029,6 & 37452,8 & 38874,3 & 40550,3 \\
\hline
\end{tabular}

Source: own processing according to EUROSTAT 